\title{
PUSAT PERTUNJUKAN DAN HIBURAN ANAK DI JAKARTA GARDEN CITY
}

\author{
Beatrix Adeline ${ }^{1)}$ \\ ${ }^{1)}$ Program Studi S1 Arsitektur, Fakultas Teknik, Universitas Tarumanagara, beatrix.ta@stu.untar.ac.id
}

\begin{abstract}
Abstrak
Maraknya isu muatan media yang tidak mendidik bagi anak-anak menginspirasi laporan akhir perancangan "Pusat Pertunjukan Anak dan Hiburan di Jakarta Garden City". Penelitian menggunakan metode pengamatan langsung dan tidak langsung untuk mengumpulkan data yang kemudian diolah dengan metode deduktif. Penulis merasa bahwa solusi tepat untuk menangani permasalahan tersebut adalah membangun wisata hiburan bagi keluarga dengan mengusung konsep atraksi arsitektur (Architectural Tourism), yakni penggunaan desain arsitek sebagai daya tarik wisata. Rancangan harus memiliki faktor atraksi, aksesibilitas, dan fasilitas untuk menciptakan lingkungan nyaman bagi pengunjung. Pemilihan lokasi jatuh pada Jakarta Garden City, Cakung (Jakarta Timur). Rancangan “Children's Perfomance \& Entertaiment Center" dirancang sebagai pusat rekreasi keluarga yang menyajikan konsep bermain sambil belajar bagi anak-anak dalam bidang seni musik dan tari dengan kisaran usia 6-12 tahun. Penelitian berfokus pada fitur alam lokasi, desain akustika, jenis kegiatan dan pertunjukan yang digelar, serta memberi perhatian khusus pada pola perilaku anak usia dini yang dapat diakomodasi rancangan arsitektur. Pusat pertunjukan ini diharapkan dapat menjadi pusat wisata dan rekreasi Jakarta, baik bagi warga sekitar maupun wisatawan. Dampak yang diharapkan adalah atraksi arsitektur ini mengurangi kecenderungan anak usia 612 tahun untuk mengonsumsi tayangan negatif di media.
\end{abstract}

Kata kunci: Anak-anak, Arsitektur, Hiburan, Pariwisata

\begin{abstract}
The flux of negative media content unsuitable for children's viewing inspired this design report entitled "Children's Performance and Entertainment Center at Jakarta Garden City". This research uses direct and indirect observation to collect data, which is then processed using the deductive method. The Author believes the aforementioned problem may be solved by building a family-friendly attraction site using the Architectural Tourism concept, which is the use of architecture design as a tourist attraction. The design must possess three factors: attraction, accessibility, and amenities, to create a comfortable environment for visitors. The chosen location is Jakarta Garden City, Cakung (Jakarta Timur). "Children's Perfomance \& Entertaiment Center" is designed as a family recreation site serving the concept of education and play for children in the 6-12 year-old range in music and dance. The research focuses on the location's natural features, acoustic design, variety of artistic activities that shall be performed, and gives special attention to children's behavior in their early age which can be accommodated by the architecture design. This site is hoped to be a recreation hub for Jakartans and visitors. The intended impact is to decrease the tendency of children aged 6-12 to consume negative media content.
\end{abstract}

Keywords: Architecture, Children, Performance, Tourism

\section{PENDAHULUAN}

Latar Belakang

Televisi merupakan salah satu media hiburan yang mudah ditemukan dan berada di hampir tiap-tiap rumah. Anak-anak menjadikan televisi ini sebagai sarana hiburan dengan mudah menonton tontonan yang belum layak baginya. Buruknya televisi akan memberi efek terhadap pertumbuhan psikologi seorang anak. dampaknya pada anak-anak dapat mempengaruhi perkembangannya, baik secara fisik, perilaku dan juga pemikirannya dan sering kali kita sebagai orang yang lebih dewasa terlambat mengetahuinya. 
Menurut Psikolog anak Vera Hadiwidjojo, Psi. dalam situs https://pinkkorset.com/2016/drama-musikal-lebih-edukatif-terhadap-anak-shrek-the-musical/ mengatakan, "memberi pertunjukan atau hiburan kepada anak seharusnya bersifat edukatif dan berkualitas untuk tumbuh kembangnya. Hal ini karena anak cenderung mengamati dan meniru hal yang ia amati."

Oleh karena itu, penulis mencetuskan untuk membuat Pusat Pertunjukan dan Hiburan Anak yang berlokasi di daerah Jakarta Garden City. Hal itu dikarenakan lokasi Jakara Garden city yang strategis dan memiliki potensi untuk berkembang dalam jangka waktu 10-15 tahun kedepan. Proyek ini bertujuan untuk memberikan hiburan dan atraksi untuk mengembangkan kreativitas dan menghibur anak-anak usia 6-12 tahun. Serta menambah hiburan dunia anakanak di Jakarta selaku generasi penerus bangsa dan menjadi salah satu pilihan hiburan keluarga di kota Jakarta dan sekitarnya.

\section{METODE}

Metode yang digunakan dalam proses Perancangan berupa:

- Tahap pengumpulan data: yaitu pengumpulan data dengan pengamatan langsung terhadap lokasi. Metode pengamatan langsung ini merupakan bagian dari tinjauan observasi yang dilakukan secara langsung dengan cara melakukan survey lokasi lapangan yang berada di sebelah.

- Tahap Analisa

- Induksi, yaitu menarik kesimpulan dari fakta-fakta yang ada.

- Komparasi, yaitu nilai, melakukan penganalisaan dengan bahan-bahan yang didapat oleh observasi, pengumpulan data dan studi literature.

- Tahap Perancangan: merupakan tahap perumusan konsep dengan menggunakan metode deduksi, yaitu membuat perumusan dari hasil induksi.

\section{DISKUSI DAN HASIL}

Tapak berada di dalam Jakarta Garden City. Jakarta Garden City (JGC) mengusung konsep "Eco Township" ini menjadi kawasan hunian modern terbesar dan terlengkap di Jakarta Timur. JGC juga menawarkan lingkungan untuk tempat tinggal, investasi, rekreasi, sekaligus yang didukung ruang terbuka hijau. Dengan lokasinya yang strategis, Jakarta Garden City menawarkan akses langsung tol JORR, tol dalam kota, dan hanya 5-kilometer dari kawasan Kelapa Gading. Aneka fasilitas di antaranya, Food Garden, IKEA, Rumah Sakit Mayapada, AEON Mall, serta akses Jalan Tipar-Cakung yang sudah beroperasi sehingga perjalanan Jakarta Garden City menuju Kelapa Gading hanya membutuhkan waktu 20 menit.

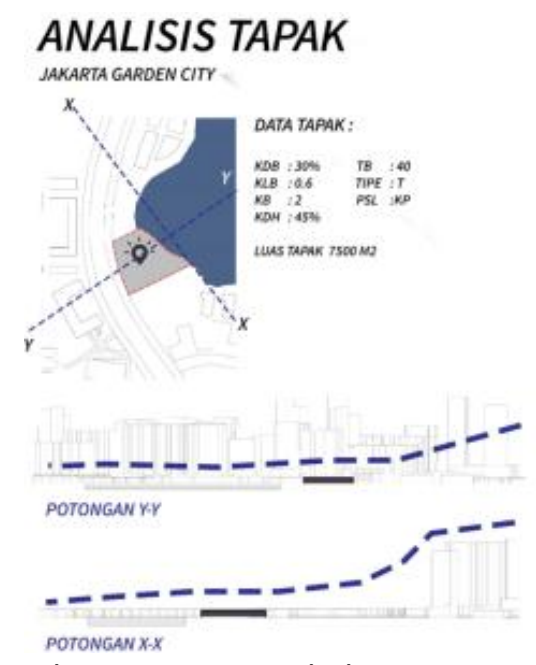

Gambar 1. Data Tapak dan Potongan Sumber: Penulis 


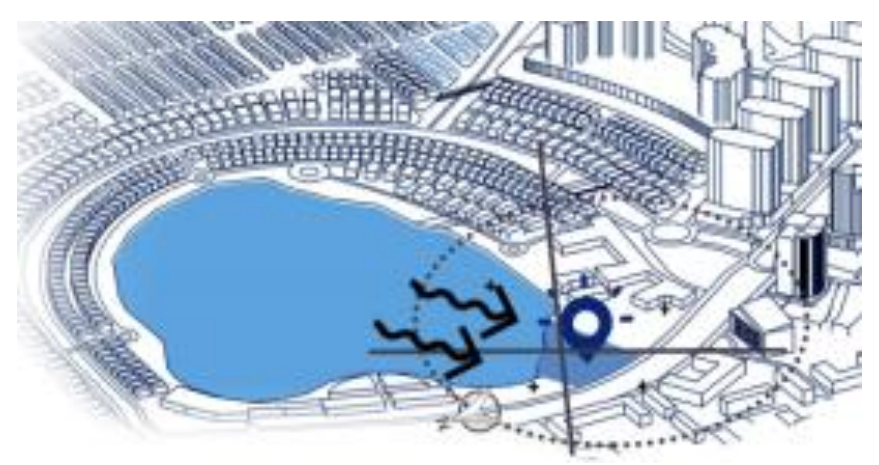

Gambar 2. Analisis Tapak

Sumber: Penulis

Pada bagian kiri, belakang dan depan tapak memiliki view yang baik, sehingga akan dibuat bukaan pada bagian tengah sehingga dapat menikmati view ke arah danau. Kemudian pada tapak tidak memiliki akses transportasi umum yang melewati lokasi. Sehingga akan dibuatnya transortasi umum berupa bus yang mengililingi area JGC. Dalam aspek kebisingan pun, pada tapak tidak memiliki kebisingan yang tinggi. Sehingga area private dapat diletakkan pada bagian depan tapak. Dari segi vegetasi, tapak memiliki daerah hijau yang tinggi. Sehingga perlakuan pada tapak akan diberi banyak pohon-pohon yang diletakkan pada bagian kanan dan kiri tapak. Hal itu dilakukan sebagai pembatas antara tapak lain dan sebagai bentuk estetika.

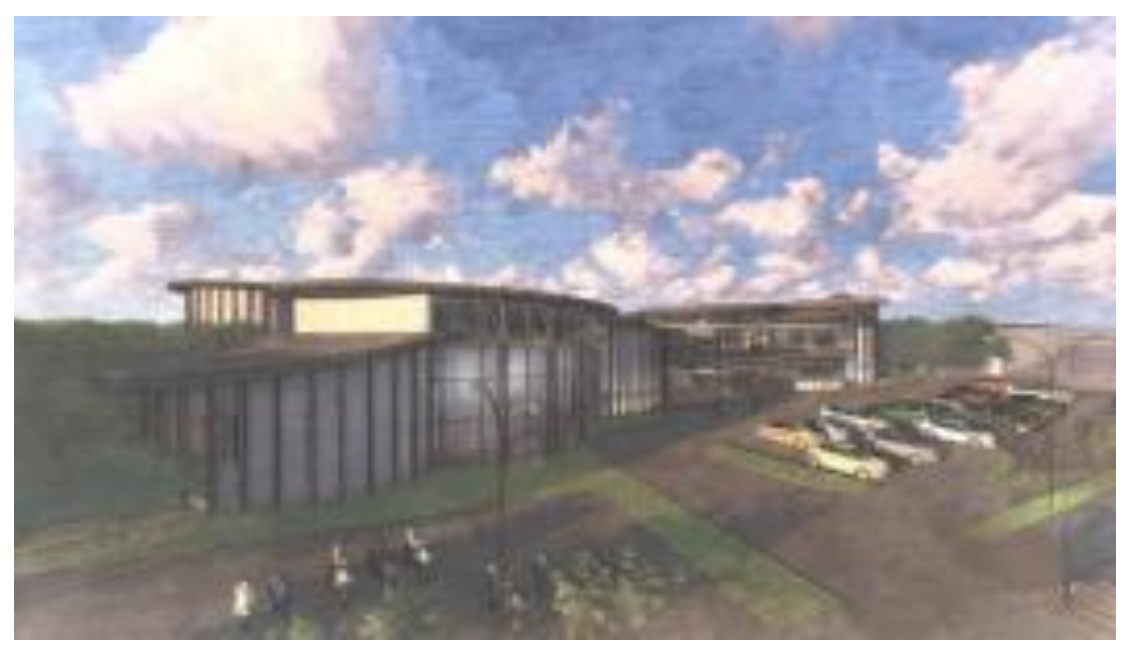

Gambar 3. Perspektif Eksterior

Sumber: Penulis

Children's Performance \& Entertainment Center ini memiliki satu gedung pertunjukan yang memiliki kapasitas untuk 350 orang. Kemudian dengan adanya danau pada bagian belakang tapak menjadi daya tarik tambahan dengan atraksi "Fountain water show" dapat diliat dari "Amphitheatre" yang membuat orang-orang dari semua kalangan dapat menikmati pertunjukan drama musikal anak-anak. Kemudian tak ketinggalan area bermain anak di dalam ruangan maupun di luar ruangan seperti indoor playground. Sedangkan area bermain outdoor seperti plaza, anak-anak dapat bermain layang-layang, berlari atau bersantai. Kemudian terdapat "Area Bermain Anak dan Belajar" yang mengajarkan berbagai macam seni mulai dari drama, musik, kesenian tradisional seperti membatik, wayang, menari. Anak-anak tidak hanya mendapatkan pengetahuan tetapi mereka dapat langsung mencoba kesenian yang mereka sukai. Serta fasilitas penunjangnya yang mendukung program "Children's Performance \& Entertainment Center" 


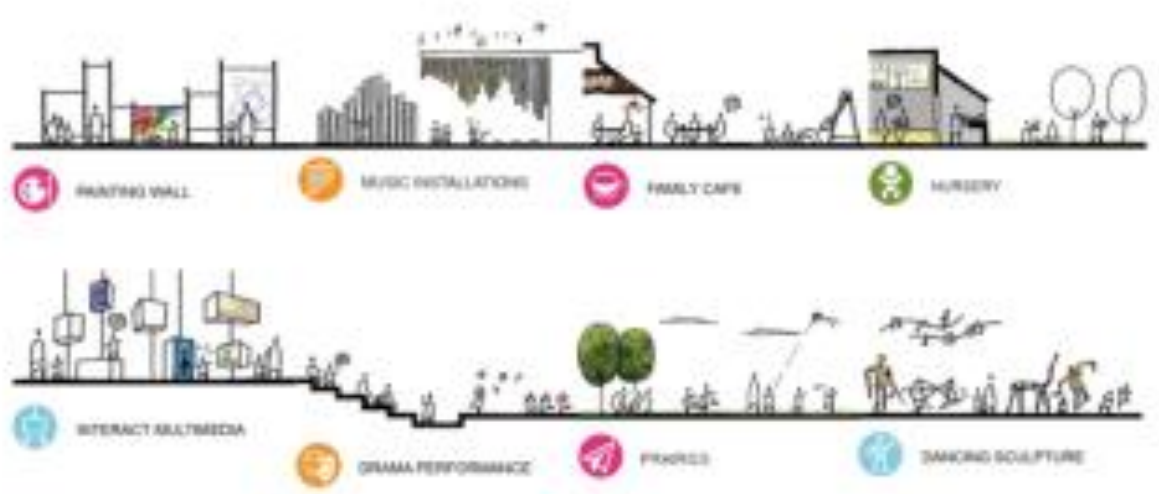

Gambar 4. Program Pada Proyek

Sumber: Pinterest

\section{SHAPE GRAMMAR}

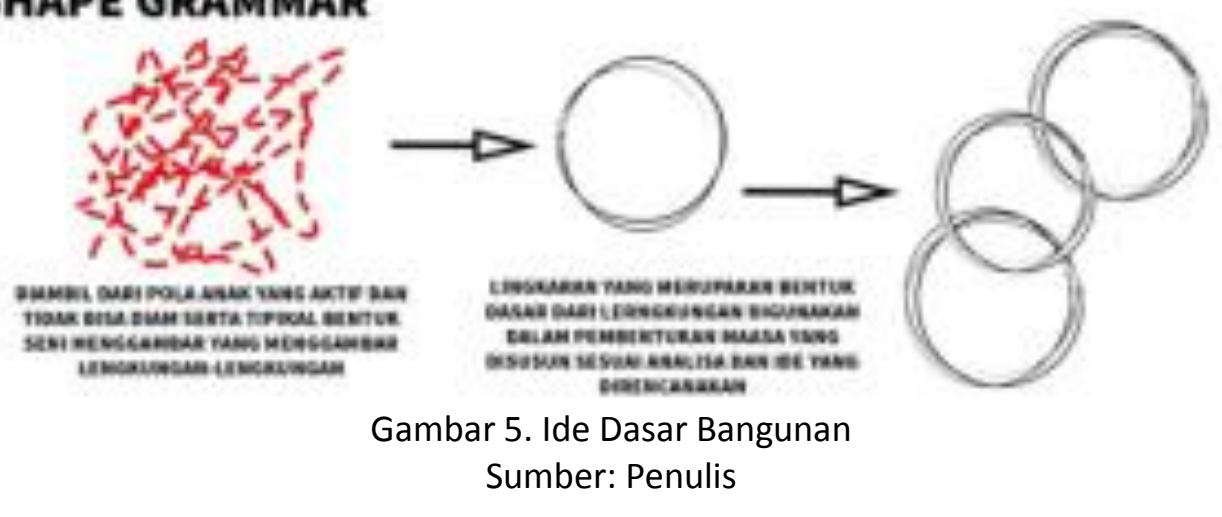

Konsep Bangunan menggunakan bentuk dasar lingkaran. Hal itu didasari oleh kepribadian anak-anak yang bebas dan tidak bisa dikendalikan. Seperti dalam menggambar yang abstrak. Kemudian sebuah studi tentang anak-anak (Tezuka, 2014) memperlihatkan alur kegiatan mereka dalam suatu bangunan. Anak-anak tersebut berkeliaran bebas, namun anak-anak kembali ke titik awal karena bentuk bangunan yang memiliki bentuk bulat. Dengan bentuk dasar lingkaran tersebut dan di gabungkan dengan metode desain Shape Grammar.

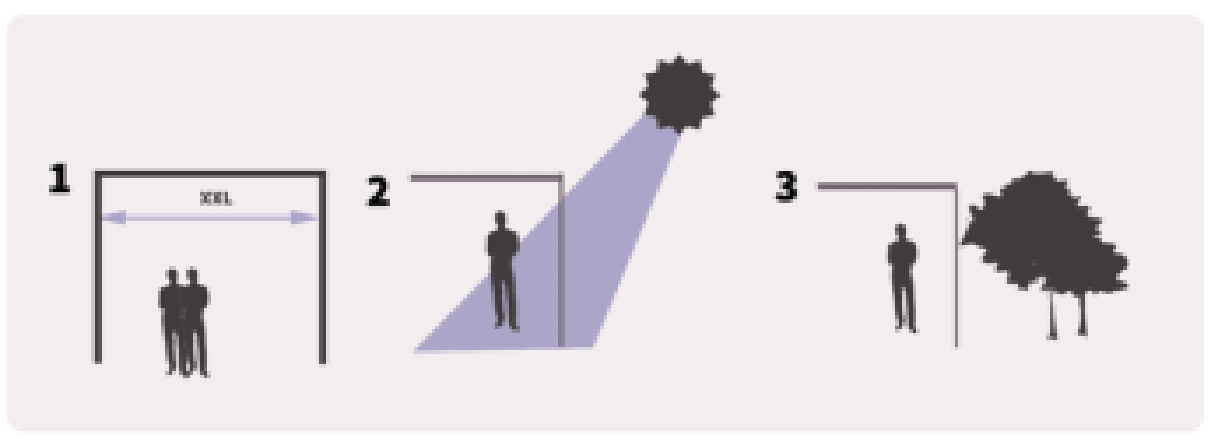

Gambar 6. Konsep Bangunan

Sumber: Penulis

Sesuai kebutuhan anak-anak dimana mereka tidak nyaman saat berada di dalam ruangan yang kecil atau sempit. Oleh karena itu ruangan kegiatan akan dibuat luas sehingga anak-anak dapat bebas beraktivitas dalam ruangan. Pada dinding, menggunakan curtain wall sehingga memberi kesan tidak ada pembatas antara bagian luar dan dalam. Dengan diberi vegetasi pada sekeliling tapak, akan menambah kesejukan dan mengurangi panas pada bangunan. 


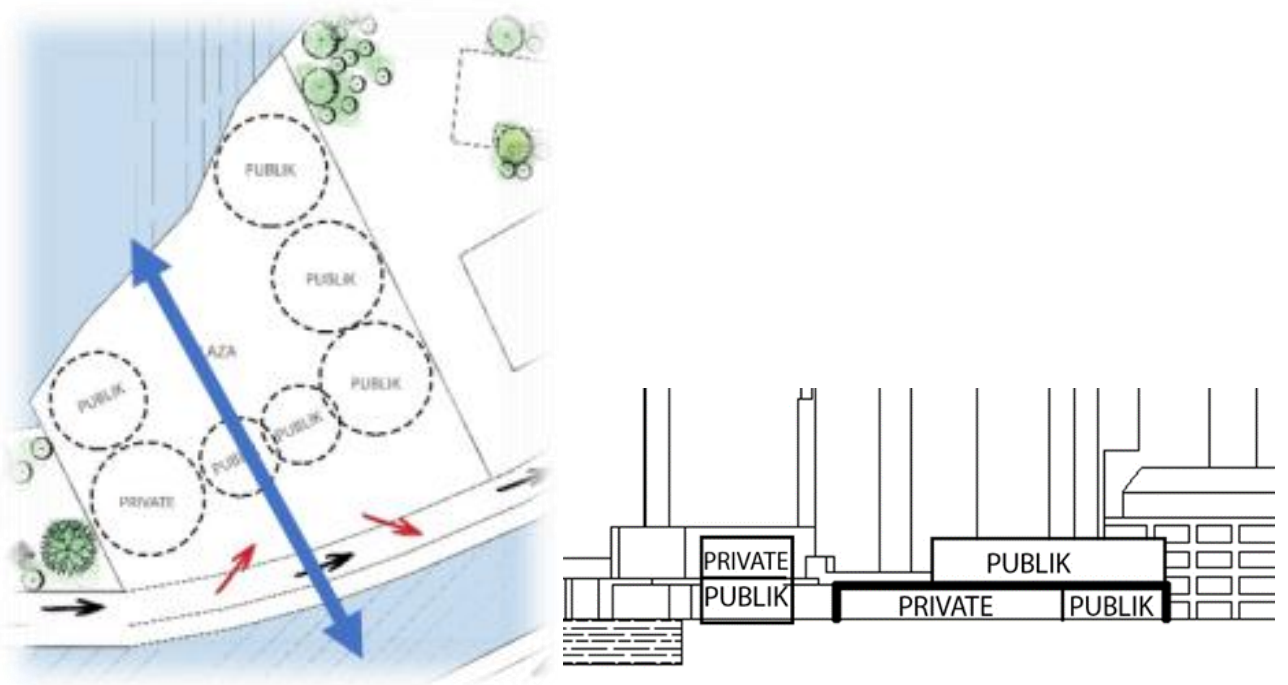

Gambar 7. Zoning

Sumber: Penulis

Dalam tahap zoning, akan terbagi menjadi tiga bagian, yaitu publik, private dan service. Pada sisi tapak depan dan belakang yang berhubungan dengan jalan dan view danau (liat garis panah biru), akan berinteraksi langsung dengan pengunjung, sehingga area tersebut akan digunakan sebagai area publik. Area public tersebut berupa plaza, entrance, dan fasilitas lainnnya. Area Private seperti ruang auditorium membutuhkan akses yang mudah, sehingga secara zonasi diletakkan pada bagian depan. Untuk bagian service akan diletakan pada bagian samping kiri dan kanan tapak. Supaya area service tidak mengganggu area private dan publik serta memberi ruang pada bagian tengah untuk mendapat view menuju danau.

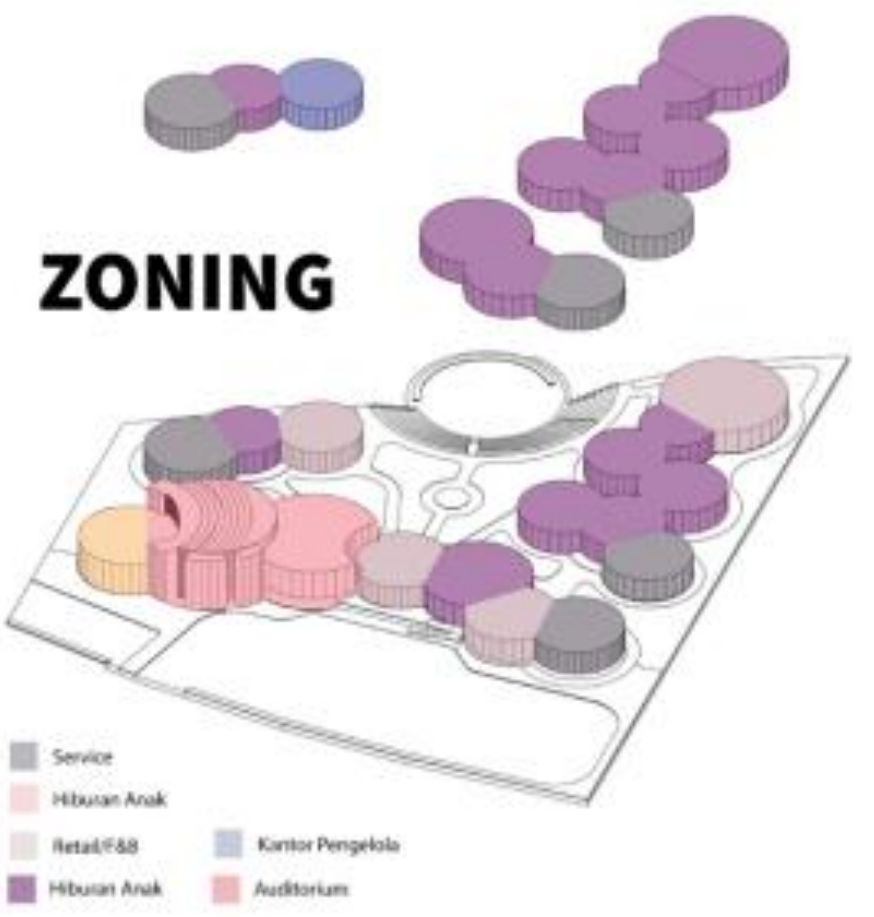

Gambar 8. Axonometri Zoning

Sumber: Penulis 


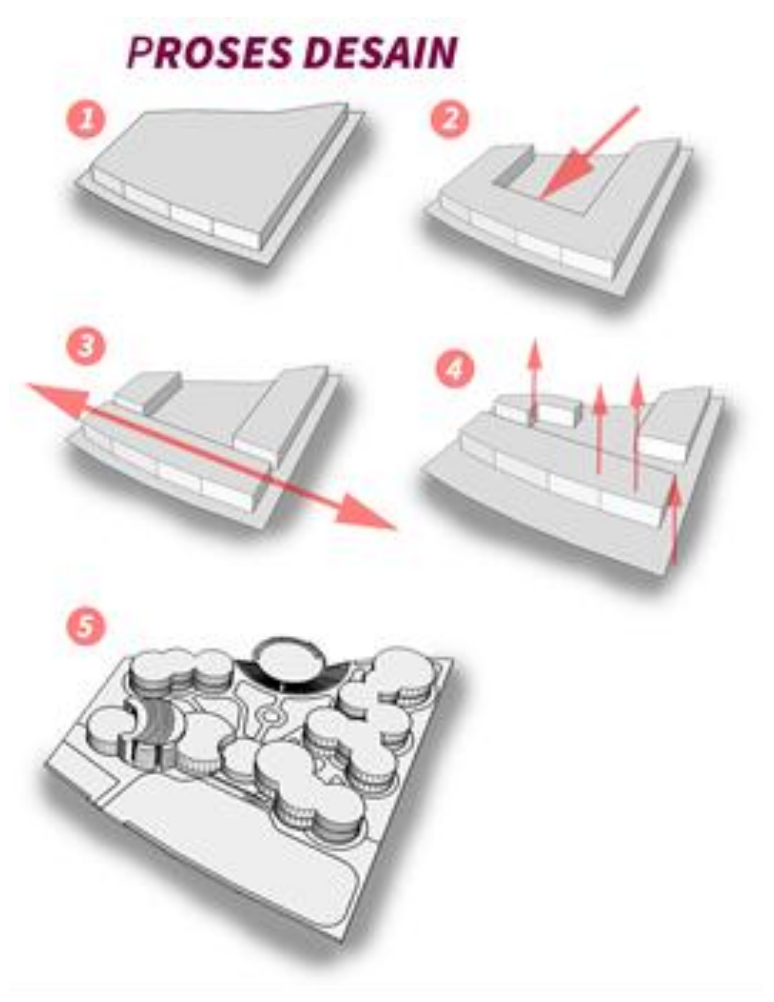

Gambar 9. Pembentukan Massa

Sumber: Penulis

Pada tahap pembentukan massa, tebagi dalam lima tahap, yaitu:

1. Program

Massa mengikuti bentuk tapak yang menghasilkan bentuk maksimal dari bentuk tapak.

2. Pendorongan

Pada bagian tengah diberi dorongan untuk diberikan sebagai ruang publik dan memberikan view ke danau.

3. Pembelahan

Agar Massa bangunan tidak padat dan Pemberian sirkulasi udara dan cahaya yang lebih baik.

4. Perluasan

Perluasan pada massa sebagai ruang terbuka publik yang menjadi konektor antara ruang terbuka sisi depan dan belakang

5. Pembentukan

Kemudian massa dibuat melengkung dengan lingkaran di tengah sebagai sumbu. lingkarang merupakan konsep dari massa terserbut.

Dalam sistem struktur, proyek ini menggunakan tipe struktur Circular, hal itu dikarenakan mengikuti bentuk massing bangunan yang berbentuk utama bulat. Struktur Circular ini lebih mudah digunakan pada bangunan khusus yang memiliki bentuk utama dengan bentuk bulat. Untuk memenuhi estetika dan konsep bangunan, bentuk kolom juga berbentuk dasar lingkaran. Pada struktur atap menggunakan struktur atap baja karena daya tahanya yang kuat dan pemeliharaan dan perawatan dari material konstruksi baja ringan juga sangat mudah dan hemat dibandingkan konstruksi lainnya. Pada plat lantai menggunakan plat lantai beton $20 \mathrm{~cm}$. 


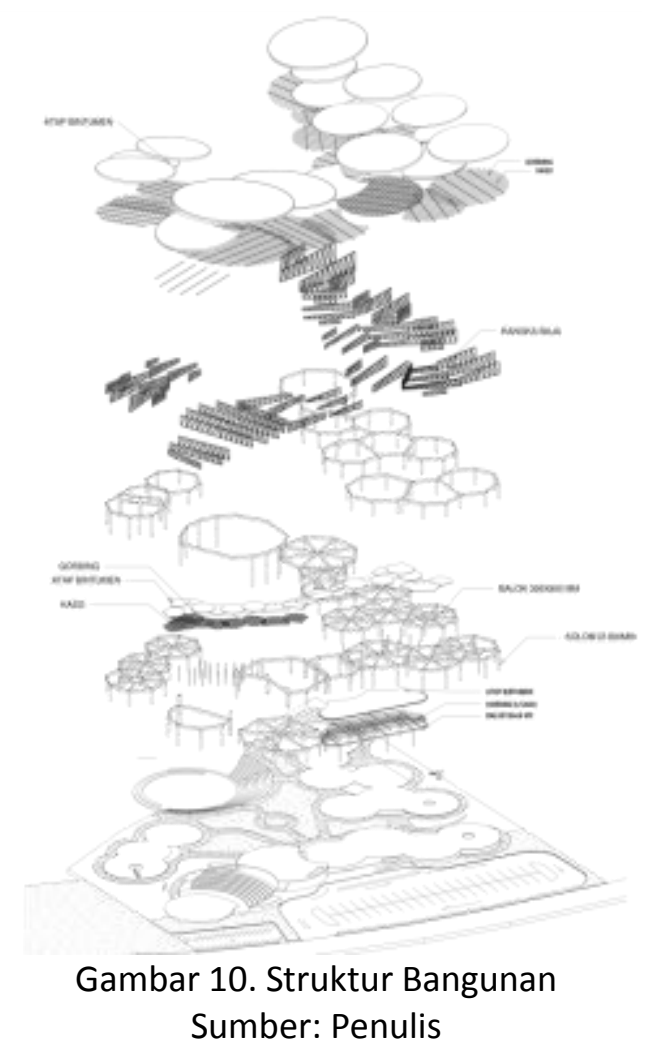

Children's Performance \& Entertaiment Center menggunakan beberapa jenis material. Pada struktur atap menggunakan jenis atap Bintumen. hal itu dikarenakan atap Bintumen dengan harga terjangkau, dapat mengurangi panas dalam bangunan, dan sangat fleksibel untuk bentuk apapun dan pada kemeringin apapun. Kemudian bangunan didominasi dengan dinding kaca sehingga anak-anak tidak merasa berada di dalam ruangan yang kecil. Pada ruang Auditorium menggunakan material Rockwool. Peredam Suara Rockwool adalah produk serat mineral ringan yang digunakan untuk membuat ruangan menjadi kedap suara sehingga tidak suara luar ruangan tidak mengganggu ruang dalam, begitupun sebaliknya.

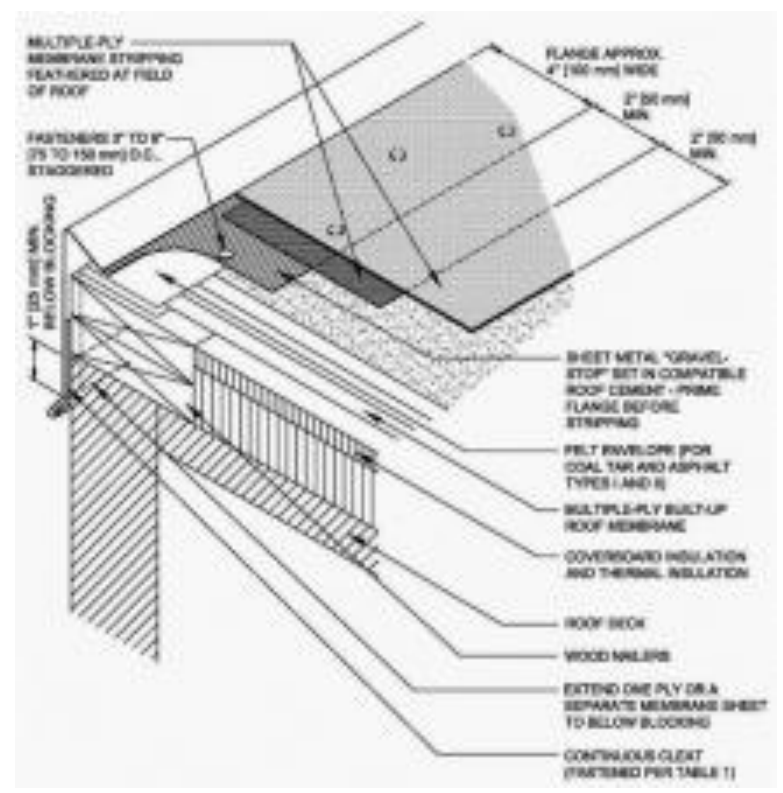

Gambar 11. Detail Atap Bintumen Sumber: Penulis 


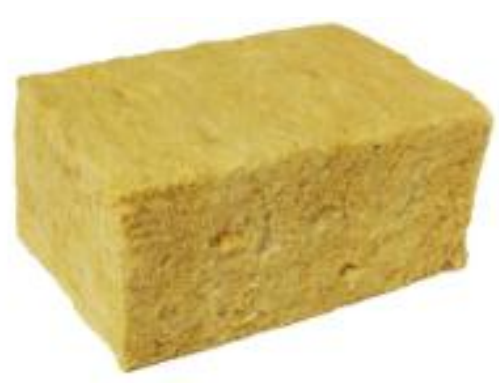

Gambar 12. Material Rockwool Sumber: Penulis

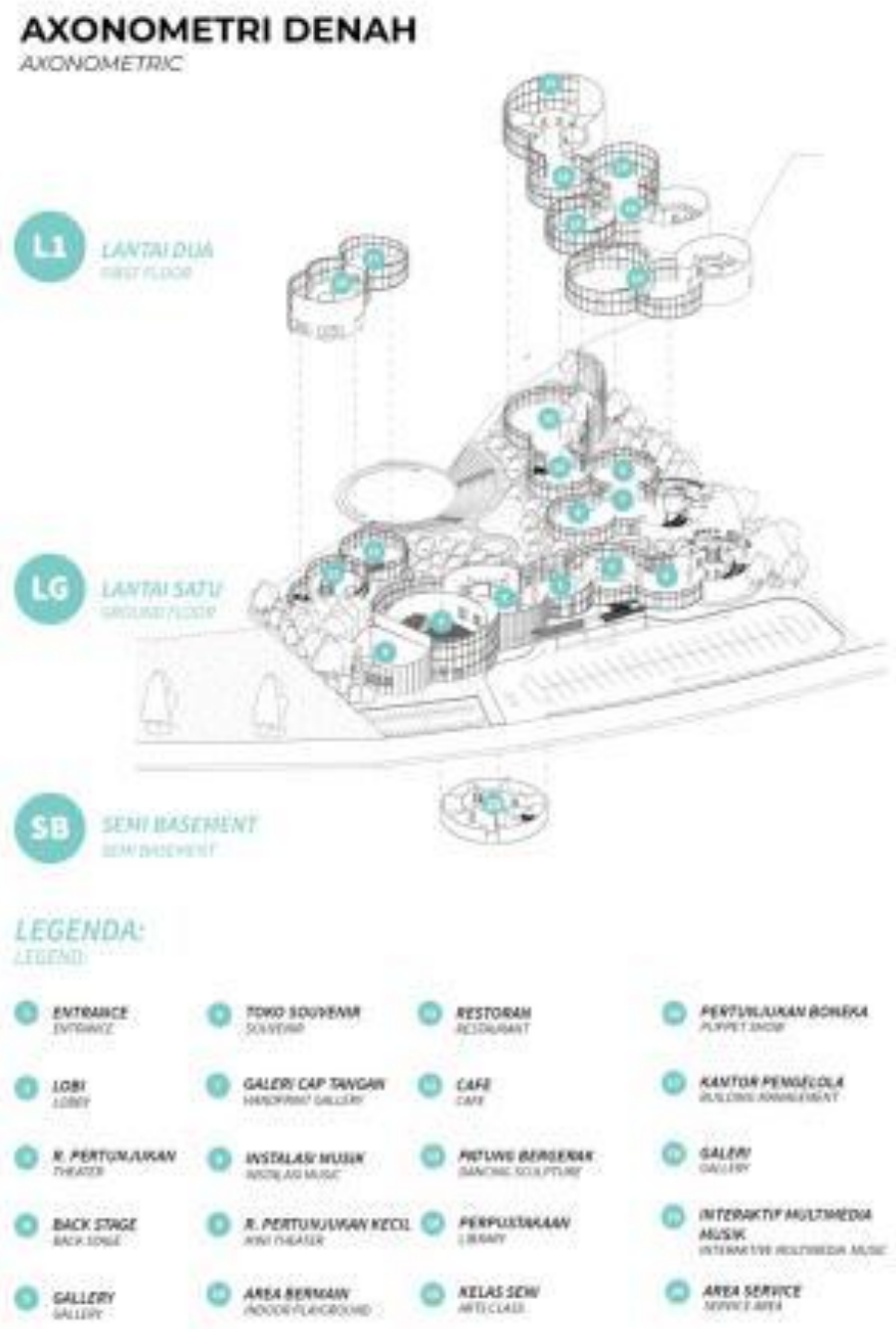

Gambar 13. Axonometri Denah Sumber: Penulis

Saat memasuki tapak, maka pengunjung dapat menuju drop off atau ke area parkir. Kemudian saat memasuki bangunan, pengunjung akan berada di area lobby dan terdapat meja resepsionis dimana pengunjung dapet bertanya atau mendapat informasi kegiatan pada bangunan. Setelah itu pengunjung dapat beraktifitas sesuai kebutuhan dan keinginan pengunjung seperti menonton pertunjukan drama musikal di ruang pertunjukan atau dapat menonton pertunjukan di amphitheater dan bermain di plaza. 


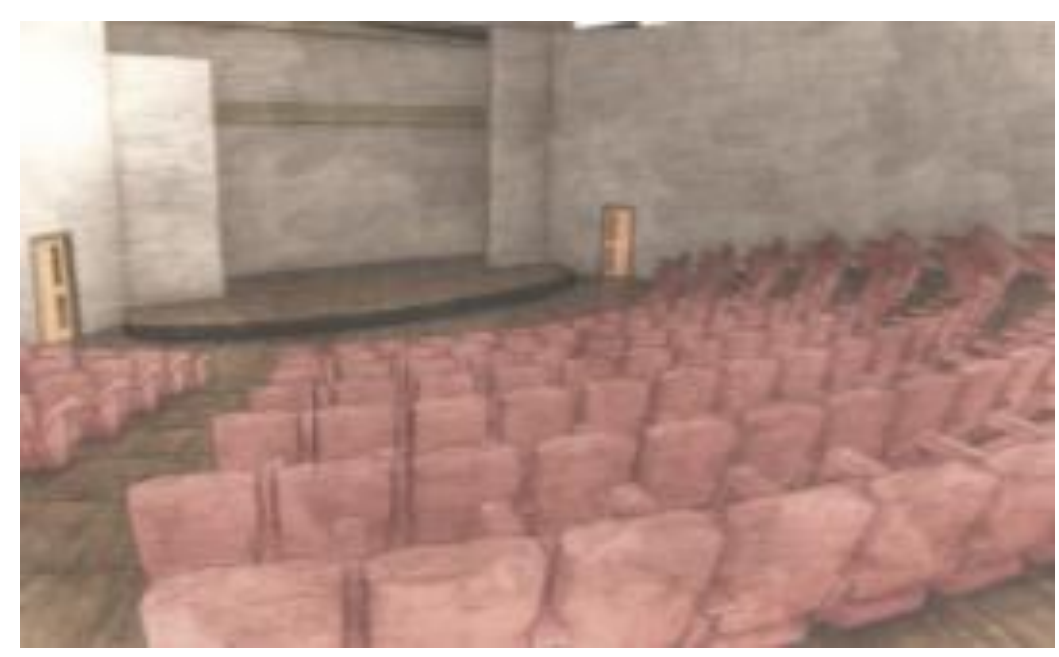

Gambar 14. Interior R. Pertunjukan

Sumber: Penulis

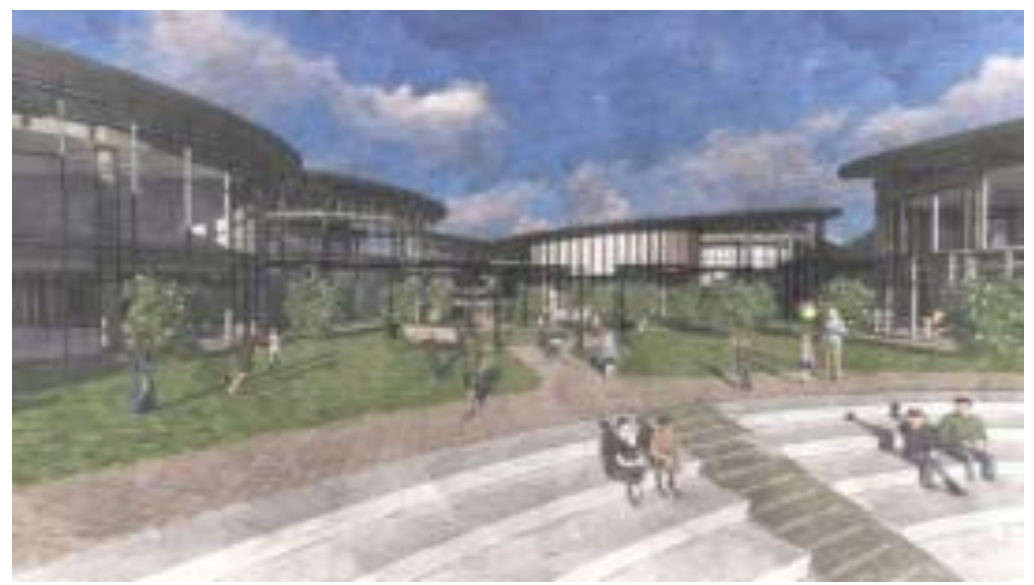

Gambar 15. Plaza dan Amphitheater

Sumber: Penulis

Penulis harus memastikan hasil penelitian beserta kajian yang dilakukan dalam makalah ini bukan merupakan hasil plagiasi. Selanjutnya, penulis secara runut dan logis perlu melakukan analisis terhadap temuan penelitian/ desain yang dihubungkan kembali dengan pertanyaan penelitian untuk membangun sebuah pengetahuan baru terkait isu yang sedang dibahas. Penulisan dapat dibagi dalam beberapa sub bagian yang diberi judul sendiri oleh penulis berdasarkan kepentingan penjelasan dengan membubuhkan nomor urut seperti pada contoh di bagian Pendahuluan.

\section{KESIMPULAN DAN SARAN}

\section{Kesimpulan}

Dalam laporan akhir perancangan ini, proyek yang diusulkan adalah Pusat Hiburan dan Rekreasi Anak di Jakarta Garden City. Pada awalnya, munculah isu anak-anak usia 6-12 tahun menjadikan televisi sebagai sarana hiburan di tiap saat waktu luang yang mereka miliki. Materi kekerasan dan tidak mendidik dalam sinetron dan kartun berdampak buruk sehingga timbulnya perilaku yang tidak pantas dilakukan pada umumnya di usia mereka.

Penulis memberi solusi untuk menangani permasalahan tersebut melalui pembangunan wisata hiburan bagi keluarga dengan mengusung konsep atraksi arsitektur (Architectural 
Tourism), sehingga keluarga dapat menikmati hiburan pertunjukan serta mengedukasi anakanak mereka. Tentunya rancangan ini diharapkan dapat menambah opsi wisata keluarga Jakarta melalui bentuk bangunan yang tidak biasa dan menjadi salah satu daya tarik para wisatawan untuk datang.

Pusat pertunjukan ini diharapkan dapat untuk mengurangi perilaku yang tidak pantas dilakukan oleh anak kecil dengan memberi hiburan edukatif berupa menonton drama musikal/pertunjukan, Kelas Seni dan Tari, pertunjukan boneka dll, dimana anak-anak dapat bermain sekaligus belajar.

\section{Saran}

Setelah mengikuti kegiatan Studio Perancangan Arsitektur VIII ini, ada beberapa hal yang dirasa perlu untuk diperhatikan lebih lanjut. Salah satunya adalah memperhatikan tontonan yang layak untuk anak kecil dan memperhatikan tumbuh kembang anak-anak sehingga dapat membentuk kepribadian para penerus bangsa yang lebih baik.

\section{REFERENSI}

Arianji, Pricilla Epifania. (2018). Architecture of Urban Tourism Landscape. Producing \& Consuming Space for Senses (hal 13-19).

Herlambang, Suryono. (2018). Architourism: heritage, iconic, spectaculture.

Mediastika, C. E., (2005), Akustika Bangunan „Prinsip-prinsip dan Penerapannya di Indonesia, Erlangga, Jakarta.

Roderick Ham, Theatre „Planning Guidance for Design and Adaptation", Butterworth Architecture, 1998

Specht, Jan. (2014). Architectural Tourism. Jerman: springer Gabler.

18 Derick Ham, Theatre „Planning Guidance for Design and Adaptation", Butterworth Architecture, 1998

https://www.kompasiana.com/anggrarendra/54f93f7ca33311ac048b49fc/kurangnya-

tayangan-tv-yang-edukatif-bagi-anak/ Artikel ini telah tayang di Tribunjateng.com dengan judul Kak Seto: Hanya 0,7 Persen Tayangan Televisi yang Mendidik Anak,

http://jateng.tribunnews.com/2016/01/11/kak-seto-hanya-07-persen-tayangan-televisi-yangmendidik-anak. Penulis: rival al-mana; Editor: iswidodo 